University of Wollongong

Research Online

Faculty of Science, Medicine and Health -

Papers: Part B

Faculty of Science, Medicine and Health

$1-1-2018$

\title{
Phytochemical studies on the Australian native plant species Acacia pycnantha and Jacaranda mimosifolia D.Don
}

Rudi Hendra

University of Wollongong, rh965@uowmail.edu.au

Paul A. Keller

University of Wollongong, keller@uow.edu.au

Follow this and additional works at: https://ro.uow.edu.au/smhpapers1

\section{Publication Details Citation}

Hendra, R., \& Keller, P. A. (2018). Phytochemical studies on the Australian native plant species Acacia pycnantha and Jacaranda mimosifolia D.Don. Faculty of Science, Medicine and Health - Papers: Part B. Retrieved from https://ro.uow.edu.au/smhpapers1/87

Research Online is the open access institutional repository for the University of Wollongong. For further information contact the UOW Library: research-pubs@uow.edu.au 


\title{
Phytochemical studies on the Australian native plant species Acacia pycnantha and Jacaranda mimosifolia D.Don
}

\author{
Abstract \\ In ongoing investigations into colours in Nature, the chemical constituents from the flowers of Acacia \\ pycnantha and Jacaranda mimosifolia D.Don grown in Australia are reported. Eight known secondary \\ metabolites were isolated from the A. pycnantha flower including isosalipurposide (7) which may be \\ responsible for their distinctive colouration. Nine secondary metabolites were isolated from the $\mathrm{J}$. \\ mimosifolia D.Don flower including the new phenylethanoid $\beta$-D-glucopyranose (10). All isolated \\ compounds were inactive against bacteria tested at concentration of $32 \mu \mathrm{g} / \mathrm{mL}$.

\section{Publication Details} \\ Hendra, R. \& Keller, P. A. (2019). Phytochemical studies on the Australian native plant species Acacia \\ pycnantha and Jacaranda mimosifolia D.Don. Natural Product Research, 33 (14), 1997-2003.
}




\title{
Phytochemical Studies on the Australian Native Plant Species Acacia pycnantha and
}

\author{
Jacaranda mimosifolia D.Don \\ Rudi Hendra ${ }^{1}$, Anthony C. Willis ${ }^{2}$ and Paul A. Keller ${ }^{1 *}$ \\ ${ }^{1}$ School of Chemistry, University of Wollongong, NSW, Australia; \\ rh965@uowmail.edu.au keller@uow.edu.au Tele: +61 242214692 \\ ${ }^{2}$ Research School of Chemistry, Australian National University, ACT, Australia; \\ willis@ rsc.anu.edu.au Tele: +61 261254109 \\ *corresponding author: E-mail: keller@uow.edu.au Phone: +61 242214692 Fax: +61 242214287
}

\begin{abstract}
In ongoing investigations into colours in Nature, the chemical constituents from the flowers of Acacia pycnantha and Jacaranda mimosifolia D.Don grown in Australia are reported. Eight known secondary metabolites were isolated from the A. pycnantha flower including isosalipurposide (7) which may be responsible for their distinctive colouration. Nine secondary metabolites were isolated from the $J$. mimosifolia D.Don flower including the new phenylethanoid $\beta$-D-glucopyranose (10). All isolated compounds were inactive against bacteria tested at concentration of $32 \mu \mathrm{g} / \mathrm{mL}$.
\end{abstract}

\section{Keywords}

Acacia pycnantha, Jacaranda mimosifolia D.Don, flavonoids, phenylethanoid, antibacterial.

\section{Introduction}

Australia has a hugely variable climate with arid, tropical, desert, alpine, and extreme conditions encompassed within the country. Australian plants have therefore developed a wide variety of survival methods specific to their environmental challenges, resulting in numerous unique morphologies and phenotypes present. A large range of introduced species have also adapted to the environment with many also cultivated (Lassak and McCarthy 2011). Numerous endogenous plants have been used as traditional medicines, however their purported biological effects are largely based on anecdotal evidence.

Acacia pycnantha (Fabaceae), commonly known as the golden wattle, is native to New South Wales, Victoria, and South Australia and has been Australia's national flower since 1988, and it grows from 3 to 8 meters in height (Ndlovu et al. 2013). The bark of this species is generally dark brown to grey and the mature trees have phyllodes (flat and widened leaf stems) which hang down from the branches. The bright yellow flowers occur in groups of 40 to 80 on $2.5-9 \mathrm{~cm}$ long raceme, which arise from auxiliary buds (Wilson et al. 2001; Ndlovu et al. 2013). This species typically flowers between November and May, though they may additionally flower several months later (Wilson et al. 2001; Ndlovu et al. 2013). Indigenous Australian people used this genus in traditional medicines and fibre craft, as well as an adhesive and as utensils (Barr et al. 1988; Murphy 2008; Clarke 2012), with its seeds also playing an important role in the diet as they are easily ground to a flour which can be mixed with water and eaten either raw or cooked to produce a type of unleavened bread (Hegarty et al. 2001). Several species such as A. kempeana, A. tetragonophylla from this genus have been reported to be prepared as antimicrobial agents (Hegarty et al. 2001), and water extract from the leaves of A. pycnantha inhibited 97\% larval development and showed anthelmintic activity toward equine cyathostomins in vitro (Payne et al. 2013). This genus is also a valuable commercial commodity, important in the flowering garden plants industry. Despite the historical and current commercial prominence, there are no phytochemical or traditional medicine studies on the flowers of this species. 
J. mimosifolia D.Don belongs to the Bignoniaceae family, and is native to Brazil. It has been cultivated in both tropical and subtropical areas of the world, and naturalised in many countries for its beautiful foliage and flowers (Moharram and Marzouk 2007; Zaghloul et al. 2011), including in Australia where it is cultivated as an ornamental plant It is a tree ranging from 1 to 45 meters tall with blue flowers which bloom in summer and are up to $5 \mathrm{~cm}$ long, and grouped in $30 \mathrm{~cm}$ panicles. The fruits of this species are oblong capsules, flattened perpendicular to the septum, and the valves either glabrous or lepidote, possessing numerous seeds. The genus of Jacaranda is commonly known as pioneer trees, because the seeds are easily grown in different climates (Gachet et al. 2010). It diverse biological activities and the chemical constituents differ in species within this genus. Jacaranone and phenylethanoids are commonly isolated from examples within this genus, with the former isolated from the leaves of J. mimosifolia D.Don along with scutellarein 7-glucuronide, verbascoside, and phenylacetic $\beta$-glucoside (Moharram and Marzouk 2007; Mostafa et al. 2014).

We have an ongoing interest in colours from Nature, concentrating particularly on flowers of plants that are both endemic and introduced to Australia (Hendra and Keller 2016, 2017), as well as any relationship between the isolated compounds and Indigenous uses. Here, we report the phytochemical studies and the antimicrobial activities of the flowers of plants species which are commonly found in the Wollongong (Australia) region. These species were selected due to their abundance, and lack of information regarding the chemical constituents present, including those responsible for their colouration.

\section{Results and Discussion}

Methanol extractions of the flowers of A. pycnantha was concentrated and sequentially solventpartitioned into $n$-hexane:MeOH resulting in polar and non-polar fractions. The chemical constituents from the non-polar fraction were analysed using GC-EIMS. The polar fractions from both species were subjected to analytical RP-HPLC followed by semi-prep RP-HPLC, which resulted in the isolation of eight compounds (Figure 1a).

The water-acetonitrile mixture containing compounds 1 (Velozo et al. 1999) and 2 (Ibrahim et al. 2007; Shimoda et al. 2010), was subjected to slow evaporation at room temperature, and afforded $\mathbf{1}$ as long white-needle crystals, with $\mathbf{2}$ isolated from the filtrate after solvent evaporation. Analysis of the LRESMS spectra of 1 indicated peaks at $\mathrm{m} / z, 457$ and 433, assigned to [M+Na] ${ }^{+}$and $[\mathrm{M}-\mathrm{H}]^{-}$respectively. ${ }^{1} \mathrm{H}$ NMR spectroscopic analysis showed two resonances at $\delta 5.29(\mathrm{dd}, J=13.0 ; 3.1 \mathrm{~Hz}), 2.97(\mathrm{dd}, J=17.2 ; 3.0 \mathrm{~Hz})$ and $2.75(\mathrm{dd}, J=17.2 ; 3.0 \mathrm{~Hz})$ assigned to the methylene protons $(\mathrm{H}-2 \& \mathrm{H}-3)$, respectively suggesting the presence of a flavanone. Furthermore, a doublet at $\delta 4.75$, with a coupling constant of $7.2 \mathrm{~Hz}$, was assigned to the anomeric proton of a glucosyl, indicating the $\beta$-configuration of the glucose moiety and the remaining proton resonances in the $\delta 3.45-4.03$ range assigned to the sugar moiety (Table S1, Figure S3, Supplementary Material). gHMBC analysis showed correlation between the resonance at $\delta_{\mathrm{H}} 4.75$, assigned to the H-1" anomeric proton, and the oxygenated carbon resonance at $\delta_{\mathrm{C}} 162.1$ (C-5) (Figure S27).

ompound 1 was optically active with a specific rotation value of $[\alpha]_{\mathrm{D}}^{22}+29.52(\mathrm{MeOH})-$ the absolute configuration was determined by comparative electronic circular dichroism (ECD) spectroscopy with a positive cotton effect observed at $334 \mathrm{~nm}(\Delta \varepsilon+0.86)$ and a negative cotton effect at $290 \mathrm{~nm}(\Delta \varepsilon-2.97)$, indicating a $2 S$ configuration, consistent with that reported ( $334 \mathrm{~nm}(\Delta \varepsilon+1.10)$ and $290 \mathrm{~nm}(\Delta \varepsilon-3.88)$ (Tyukavkina et al. 1989). Finally, the absolute configuration of compound 1 was confirmed from the analysis of its single crystal X-ray crystallographic data. The refined Hooft parameter was -0.04 (8) for 1026 Friedel-pairs and the bond lengths and angles between fused ring $\mathrm{C}$ and $\mathrm{B}$ was observed at $104.6^{\circ}$ by using Spartan version 16 (supporting information, F26) Therefore it was confirmed a $(2 S)$ configuration (Figure S26) and compound 1 was identified as (2S)-naringenin 5-O- $\beta$-D-glucopyranose.

Analysis of the spectroscopic data of compound $\mathbf{2}$ revealled similarities to compound $\mathbf{1}$, however gHMBC analysis showed a correlation between the resonance at $\delta_{\mathrm{H}} 4.75(\mathrm{~d}, J=9.8 \mathrm{~Hz})$, assigned to the $\mathrm{H}-1$ " anomeric proton, and the carbon resonance at $\delta_{\mathrm{C}} 106.1(\mathrm{C}-8)$, indicating a C-C bond link between naringenin to the glucosyl anomeric proton (Figure S27), with 2 identified as isohemiphloin (Hillis and 
Horn 1965). It was also optically active with a specific rotation of $[\alpha]_{\mathrm{D}}^{22} 97.79(\mathrm{MeOH})$, and further analysis of the ECD spectrum indicated a positive cotton effect at $334 \mathrm{~nm}(\Delta \varepsilon+2.80)$ and a negative cotton effect at $290 \mathrm{~nm}(\Delta \varepsilon-4.06)$ (Xiao et al. 2012). Compound 8 was identified as the parent heterocycle naringenin and was spectroscopically identical to that reported (Shimoda et al. 2010). In the same manner, compound $\mathbf{8}$ showed $2 S$ absolute configuration with positive cotton effect at $334 \mathrm{~nm}(\Delta \varepsilon$ +1.39 , lit $\Delta \varepsilon+0.89$ (Caccamese et al. 2005) ) negative cotton effect at $287 \mathrm{~nm}(\Delta \varepsilon-6.07$, lit $\Delta \varepsilon-4.20$ (Caccamese et al. 2005)).

A

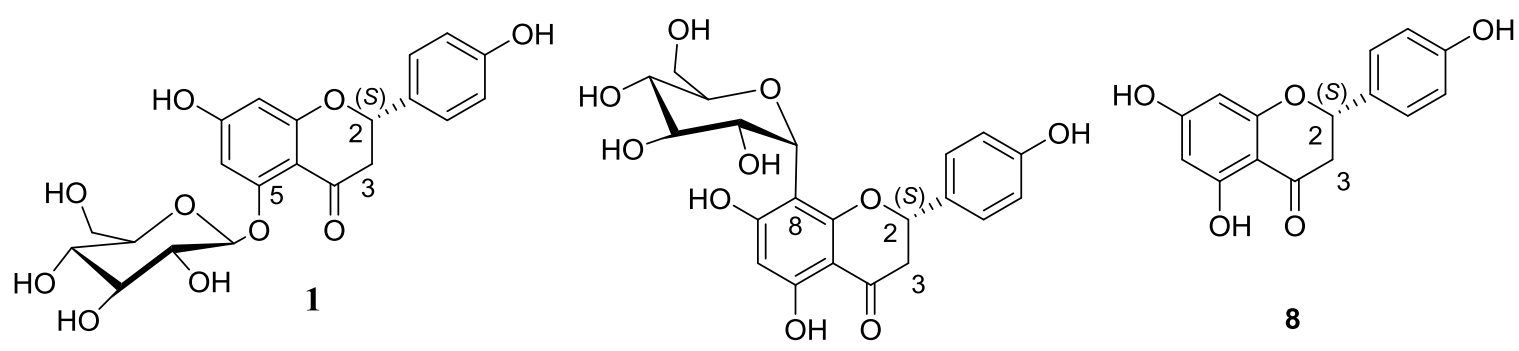<smiles></smiles>

2

$$
\begin{array}{ll}
\mathbf{3} \mathrm{R}_{1}=\mathrm{R}_{2}=\mathrm{R}_{3}=\mathrm{OH} & \mathbf{4} \mathrm{R}_{1}=\mathrm{R}_{2}=\mathrm{OH} \mathrm{R} \mathrm{R}_{3}=\text { rutinosyl } \\
\mathbf{6} \mathrm{R}_{1}=\mathrm{H} \mathrm{R}_{2}=\mathrm{R}_{3}=\mathrm{OH} & \mathrm{5R}_{1}=\mathrm{H} \mathrm{R}_{2}=\mathrm{OH} \mathrm{R} \mathrm{R}_{3}=\text { glucose }
\end{array}
$$

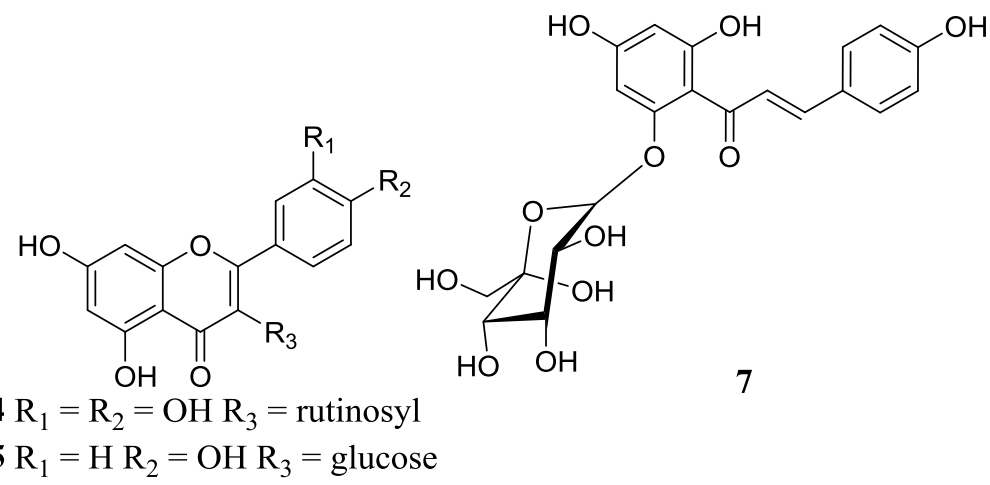

B<smiles>[R20]OC1OC(OC(=O)CC2(O)C=CC(=O)C=C2)C(O[R20])C([R3])C1O</smiles><smiles>CC(=O)Cc1ccc(O)cc1</smiles>

14<smiles>CC(=O)Cc1ccccc1</smiles>

16<smiles>CC(=O)Cc1ccc(O)cc1</smiles><smiles>CC(=O)Cc1ccccc1</smiles>

17<smiles>CC(=O)Cc1ccccc1</smiles>

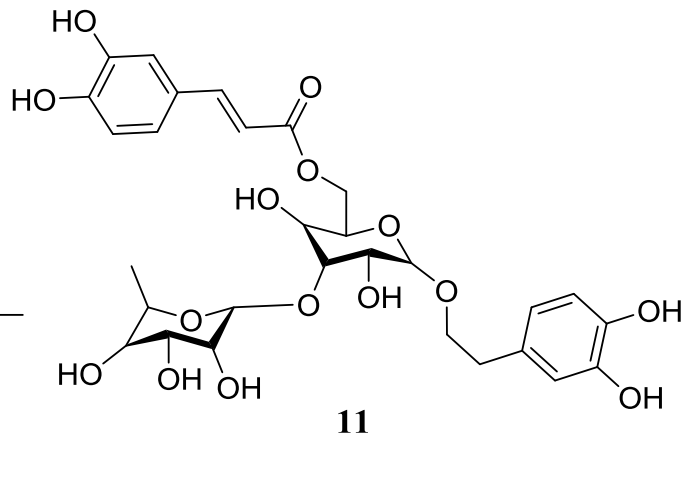

11<smiles></smiles>

15<smiles>O=C1C=CC(CC(=O)O)C=C1</smiles> 
Figure 1. Molecular structures of compounds isolated from the flowers of A. pycnantha (1-8) (A) and $J$. mimosifolia D.Don (9 - 17) (B).

Compound 1 was optically active with a specific rotation value of $[\alpha]_{\mathrm{D}}^{22}+29.52(\mathrm{MeOH})-$ the absolute configuration was determined by comparative electronic circular dichroism (ECD) spectroscopy with a positive cotton effect observed at $334 \mathrm{~nm}(\Delta \varepsilon+0.86)$ and a negative cotton effect at $290 \mathrm{~nm}(\Delta \varepsilon-2.97)$, indicating a $2 S$ configuration, consistent with that reported ( $334 \mathrm{~nm}(\Delta \varepsilon+1.10)$ and $290 \mathrm{~nm}(\Delta \varepsilon-3.88)$ (Tyukavkina et al. 1989). Finally, the absolute configuration of compound 1 was confirmed from the analysis of its single crystal X-ray crystallographic data. The refined Hooft parameter was -0.04 (8) for 1026 Friedel-pairs and the bond lengths and angles between fused ring $\mathrm{C}$ and $\mathrm{B}$ was observed at $104.6^{\circ}$ by using Spartan version 16 (supporting information, F26) Therefore it was confirmed a $(2 S)$ configuration (Figure S26) and compound 1 was identified as (2S)-naringenin 5-O- $\beta$-D-glucopyranose.

Analysis of the spectroscopic data of compound 2 revealled similarities to compound $\mathbf{1}$, however gHMBC analysis showed a correlation between the resonance at $\delta_{\mathrm{H}} 4.75(\mathrm{~d}, J=9.8 \mathrm{~Hz})$, assigned to the $\mathrm{H}-1$ " anomeric proton, and the carbon resonance at $\delta_{\mathrm{C}} 106.1(\mathrm{C}-8)$, indicating a $\mathrm{C}-\mathrm{C}$ bond link between naringenin to the glucosyl anomeric proton (Figure S27), with $\mathbf{2}$ identified as isohemiphloin (Hillis and Horn 1965). It was also optically active with a specific rotation of $[\alpha]_{\mathrm{D}}^{22} 97.79(\mathrm{MeOH})$, and further analysis of the ECD spectrum indicated a positive cotton effect at $334 \mathrm{~nm}(\Delta \varepsilon+2.80)$ and a negative cotton effect at $290 \mathrm{~nm}(\Delta \varepsilon-4.06)$ (Xiao et al. 2012). Compound 8 was identified as the parent heterocycle naringenin and was spectroscopically identical to that reported (Shimoda et al. 2010). In the same manner, compound $\mathbf{8}$ showed $2 S$ absolute configuration with positive cotton effect at $334 \mathrm{~nm}(\Delta \varepsilon$ +1.39 , lit $\Delta \varepsilon+0.89$ (Caccamese et al. 2005) ) negative cotton effect at $287 \mathrm{~nm}(\Delta \varepsilon-6.07$, lit $\Delta \varepsilon-4.20$ (Caccamese et al. 2005)).

During the isolation procedure, compounds 3, 4, and 5 (Kazuma et al. 2003) were collected as one fraction, and required re-separation by preparative RP-HPLC, affording myricetin 3-rhamnodise (3), quercetin 3-glucoside (4), and kaempferol 3-rutinoside (5). The two major constituents contained within the flowers were isolated at $t_{R} 15.0(6)$ and $17.8(7)$ minutes with compound $\mathbf{6}$ assigned as kaempferol-3rhamnoside (Güvenalp and Demirezer 2005). Compound 7 was identified as the chalcone glycoside isosalipurposide (Ghribia et al. 2014), and is responsible for the distinctive yellow colouration of the $A$. cyaophylla flowers.

The polar extract from J. mimosifolia D.Don flowers was subjected to reverse-phase HPLC, with optimal conditions using a gradient elution $(100 \%$ to $60 \%)$ of solvent A $(0.1 \%$ trifluoroacetic acid in water) over 40 minutes with solvent B ( $0.1 \%$ trifluoroacetic acid in acetonitrile). Preparative RP-HPLC afforded the separation of nine compounds (Figure 1B) including five jacarnanone-derived glucosidic esters $(\mathbf{1 3}, \mathbf{1 4}$, 16, 17 (Gachet et al. 2010; Rana et al. 2013)) and the new jacarananone-derived glucosidic ester (10), alongside potential degradation products 9 (Gachet et al. 2010) and 12 (Gachet et al. 2010). The known phenylpropanoid glucoside (11) (Zaghloul et al. 2011) and apigenin 7- $\beta$-glucoside (15) (Vanhoenacker et al. 2002) were also separated.

Compounds 16 and 17 were identified as Jacaglabroside C and D, previously isolated from J. glabra (Gachet et al. 2010); compounds 13, 14, 16, 17 were reported for the first time from the flowers of $J$. mimosifolia D.Don.

Compound 10 was isolated as a yellow gum. The LRESIMS of $\mathbf{1 0}$ showed a peak at $\mathrm{m} / z 353[\mathrm{M}+\mathrm{Na}]^{+}$ and analysis of the HRESIMS showed a peak at $m / z 353.0839$ (Calcd. for $\mathrm{C}_{14} \mathrm{H}_{18} \mathrm{O}_{9} \mathrm{Na}^{+}, 353.0849$ ). Analysis of the ${ }^{1} \mathrm{H}$ and HSQC NMR spectra indicated the presence of an aromatic substituted sugar unit, identified as $\beta$-D-glucopyranose moiety (Table S18).

Analysis of the ${ }^{1} \mathrm{H}$ NMR spectrum showed a large coupling constant for the anomeric protons at $\delta_{\mathrm{H}} 5.42$ $(J=8.2 \mathrm{~Hz})$, therefore the sugar was assigned as the $\beta$-anomeric sugar configuration (Duus et al. 2000). Furthermore, a pair of resonances at $\delta_{\mathrm{H}} 7.01(\mathrm{~d}, J=8.5 \mathrm{~Hz}, 2 \mathrm{H})$ and $6.13(\mathrm{~d}, J=8.5 \mathrm{~Hz}, 2 \mathrm{H})$ were assigned as $\mathrm{H}^{-2} / 6^{\prime}$ and $\mathrm{H}-3^{\prime} / 5^{\prime}$, respectively, which showed gHMBC correlations with resonances at $\delta_{\mathrm{C}}$ 
44.3, 67.4, 187.1, which were assigned as C-7', C-1', and C-4', respectively (Figure S28). In addition, ${ }^{1} \mathrm{H}$ NMR spectroscopic analysis showed a resonance at $\delta_{\mathrm{H}} 2.84(\mathrm{~s})$, assigned as the methylene proton $\mathrm{H}^{-7} 7^{\prime}$ which showed two bond and three bond correlations with quaternary carbons resonances at $\delta_{\mathrm{C}} 168.8$ and 152.5 assigned to $\mathrm{C}-8^{\prime}$ and $\mathrm{C}-2^{\prime} / \mathrm{C}^{\prime}$ ', respectively, allowing the identification of a jacaranone ester moiety. Further gHMBC spectral anlysis showed a proton-carbon correlation from $\mathrm{H} 1$ to $\mathrm{C}-8$ ' establishing the position of the link between the sugar with jacaranone acid moiety at the C1 of the sugar (Figure S28). In addition, acid hydrolysis of $\mathbf{1 0}$ indicated the presence of a $\beta$-D-glucopyranose moiety via HPLC comparison to authentic standards at retention time $8.33 \mathrm{~min}$. Therefore, compound $\mathbf{1 0}$ was proposed as a new phenylethanoid $\beta$-D-glucopyranose.

The Australian Indigenous people in northern New South Wales have used about 150 species of plants as antiseptic agents (Palombo and Semple 2001; Cock 2007), with Alocasia brisbanensis, Corymbia intermedia, Crinum asiaticum, and Syncarpia glomulifera used to disinfect wounds (Lassak and McCarthy 2011; Packer et al. 2015). Therefore, the methanol extracts from both species, and the isolated compounds $(\mathbf{1}-\mathbf{1 7})$, were screened for their antibacterial activities against five bacteria and two fungi at $32 \mu \mathrm{g} / \mathrm{mL}$. Their activities were analysed based on the ability of the sample to inhibit the growth of microorganisms equal or more than $80 \%$ with Z-score $\geq 2.5$. All compounds were inactive against all the tested microorganisms based on this criteria (Table S19).

Although the above compounds tested inactive (against microorganism), there are reports of other biological activities associated with the compounds isolated in this study. For example, naringenin and naringenin glucosides $(\mathbf{1}, \mathbf{2}, \mathbf{8})$ are reported to exhibit hydroxyl and superoxide radical scavenger efficiency and also showed effectiveness in protection against oxidative damage to lipids in a dosedependent manner (Patel et al. 2014). Furthermore, chalcone (7) has reported anti-infective, antiinflammatory and cytotoxic properties (Rozmer and Perjési 2016). Ghribia et al reported that compound 7, isolated from A. cyanophylla flowers, was found to be active against acetylcholinesterase with an $\mathrm{IC}_{50}$ value of $52.04 \mu \mathrm{g} / \mathrm{mL}$ (Ghribia et al. 2014).

Furthermore, the leaves and bark of J. mimosifolia D.Don have been used in traditional medicine in Brazil, Argentina, and Ecuador to treat sexually transmitted disease and blood purification (Zaghloul et al. 2011). Previous studies reported compounds 14, 16, 17 as active in vitro against $P$. falciparum $\mathrm{K} 1$ strain with $\mathrm{IC}_{50}$ values of $0.56,0.56$, and $0.55 \mu \mathrm{g} / \mathrm{ml}$, respectively (Gachet et al. 2010).

\section{Conclusion}

Eight secondary metabolites were identified from the A. pycnantha flower including isosalipurposide (7) which may be responsible for their distinctive colouration. Nine secondary metabolites were isolated from the J. mimosifolia D.Don flower including the new phenylethanoid $\beta$-D-glucopyranose (10). All isolated compounds were inactive against bacteria tested at concentration of $32 \mu \mathrm{g} / \mathrm{mL}$.

\section{Acknowledgment}

Antimicrobial screening was performed by CO-ADD (The Community for Antimicrobial Drug Discovery), funded by the Wellcome Trust (UK) and The University of Queensland (Australia).

\section{Supplemental Material}

Details including general reaction procedures, Spectral data, HPLC profiles, GCMS, antimicrobial data, and NMR spectra data of compounds 1-17 including 2D NMR spectra data of compound 10, and the Xray crystal structure for compound $\mathbf{1}$ are available.

\section{References}

Barr A, Alexander V, Andrews M, Knight T. 1988. Traditional bush medicines: an Aboriginal pharmacopoeia. Richmond, Victoria: Greenhouse Publication Pty Ltd. 
Caccamese S, Caruso C, Parrinello N, Savarino A. 2005. High-performance liquid chromatographic separation and chiroptical properties of the enantiomers of naringenin and other flavanones. $\mathrm{J}$ Chromatogr A. 1076(1):155-162.

Clarke PA. 2012. Australian Plants as Aboriginal Tools. Kenthurst, NSW: Rosenberg Publishing.

Cock I. 2007. Antibacterial Activity of selected Australian native plant extracts. Internet J Microbiol. $4(2): 1-9$.

Duus JØ, Gotfredsen CH, Bock K. 2000. Carbohydrate structural determination by NMR spectroscopy: modern methods and limitations. Chem Rev. 100(12):4589-4614.

Gachet MS, Kunert O, Kaiser M, Brun R, Munoz RA, Bauer R, Schühly W. 2010. Jacaranone-derived glucosidic esters from Jacaranda glabra and their activity against Plasmodium falciparum. J Nat Prod. 73(4):553-556.

Ghribia L, Ghouilaa H, Omrib A, Besbesb M, Janneta HB. 2014. Antioxidant and antiacetylcholinesterase activities of extracts and secondary metabolites from Acacia cyanophylla. Asian Pac J Trop Biomed. 4:417-423.

Güvenalp Z, Demirezer LÖ. 2005. Flavonol glycosides from Asperula arvensis L. Turk J Chem. 29(2):163-169.

Hegarty MP, Hegarty EE, Wills RBH. 2001. Food safety of Australian plant bushfoods. Kingston ACT: RIRDC Publication.

Hendra R, Keller PA. 2016. Flowers in Australia: Phytochemical Studies on the Illawarra Flame Tree and Alstonville. Aust J Chem. 69:925-927.

Hendra R, Keller PA. 2017. Phytochemical Studies on Two Australian Anigozanthos Plant Species. J Nat Prod. 80(7):2141-2145.

Hillis W, Horn D. 1965. Nuclear magnetic resonance spectra and structures of some C-glycosyl flavonoids. Aust J Chem. 18(4):531-542.

Ibrahim LF, El-Senousy WM, Hawas UW. 2007. NMR spectral analysis of flavonoids from Chrysanthemum coronarium. Chem Nat Compd. 43(6):659-662.

Kazuma K, Noda N, Suzuki M. 2003. Malonylated flavonol glycosides from the petals of Clitoria ternatea. Phytochemistry. 62:229-237.

Lassak EV, McCarthy T. 2011. Australian Medicinal Plants. Sydney: Reed New Holland.

Moharram FA, Marzouk MS. 2007. A novel phenylethanoid dimer and flavonoids from Jacaranda mimosaefolia. Z Naturforsch B Chem Sci. 62(9):1213-1220.

Mostafa NM, Eldahshan OA, Singab ANB. 2014. The genus Jacaranda (Bignoniaceae): an updated review. Phmarcacogn Commun. 4(3 - 39):31.

Murphy DJ. 2008. A review of the classification of Acacia (Leguminosae, Mimosoideae). Muelleria. 26(1):10-26.

Ndlovu J, Richardson DM, Wilson JRU, O'Leary M, Le Roux JJ. 2013. Elucidating the native sources of an invasive tree species, Acacia pycnantha, reveals unexpected native range diversity and structure [Article]. Ann Bot. 111(5):895-904.

Packer J, Naz T, Harrington D, Jamie JF, Vemulpad SR. 2015. Antimicrobial activity of customary medicinal plants of the Yaegl Aboriginal community of northern New South Wales, Australia: a preliminary study. BMC Res Notes. 8(1):1-7.

Palombo EA, Semple SJ. 2001. Antibacterial activity of traditional Australian medicinal plants. J Ethnopharmacol. 77(2):151-157.

Patel K, Singh GK, Patel DK. 2014. A review on pharmacological and analytical aspects of naringenin. Chin J Integr Med.1-13.

Payne S, Kotze A, Durmic Z, Vercoe P. 2013. Australian plants show anthelmintic activity toward equine cyathostomins in vitro. Vet Parasitol. 196(1-2):153-160.

Rana A, Bhangalia S, Singh HP. 2013. A new phenylethanoid glucoside from Jacaranda mimosifolia. Nat Prod Res. 27(13):1167-1173.

Rozmer Z, Perjési P. 2016. Naturally occurring chalcones and their biological activities. Phytochem Rev. 15(1):87-120. 
Shimoda K, Kubota N, Taniuchi K, Sato D, Nakajima N, Hamada H, Hamada H. 2010. Biotransformation of naringin and naringenin by cultured Eucalyptus perriniana cells. Phytochemistry. 71(2):201-205.

Tyukavkina MA, Dem'yanovich VM, Kolesnik YA, Ruchkin VE, Rulenko IA, Litvinenko VI. 1989. Configuration of stereoisomers of naringenin 5-glucoside present in flamin. Chem Nat Compd. 25(2):157-160.

Vanhoenacker G, Van Rompaey P, De Keukeleire D, Sandra P. 2002. Chemotaxonomic features associated with flavonoids of cannabinoid-free cannabis (Cannabis sativa subsp. sativa L.) in relation to hops (Humulus lupulus L.). Nat Prod Lett. 16:57-63.

Velozo LSM, Da Silva BP, Da Silva EMB, Parente JP. 1999. Constituents from the roots of Bowdichia virgilioides. Fitoterapia. 70(5):532-535.

Wilson AJ, Scientific C, Orchard AE. 2001. Flora of Australia. Vol. 11. Canberra: CSIRO.

Xiao Z, Wang F, Yin H, Sun A, Li C, Li Q, Zhang S. 2012. A new flavanone glucoside from Abrus precatorius. Chem Nat Compd. 48(4):565-567.

Zaghloul A, Gohar A, Ahmad M, Baraka H, El-Bassuony A. 2011. Phenylpropanoids from the stem bark of Jacaranda mimosaefolia. Nat Prod Res. 25(1):68-76. 